\title{
Royal Executions: Evidence Bearing on the Subject of Sanctioned Killing in the Middle Kingdom
}

Kerry M. Muhlestein

kerry_muhlestein@byu.edu

Follow this and additional works at: https://scholarsarchive.byu.edu/facpub

Part of the Biblical Studies Commons, and the Other Religion Commons

\section{Original Publication Citation}

Royal Executions: Evidence Bearing on the Subject of Sanctioned Killing in the Middle Kingdom, in The Journal of the Economic and Social History of the Orient, 51/2 (28): 181-28.

\section{BYU ScholarsArchive Citation}

Muhlestein, Kerry M., "Royal Executions: Evidence Bearing on the Subject of Sanctioned Killing in the Middle Kingdom" (2008). Faculty Publications. 891.

https://scholarsarchive.byu.edu/facpub/891 
Page 181

\title{
"Royal Executions: Evidence Bearing on the Subject of Sanctioned Killing in the Middle Kingdom," in The Journal of the Economic and Social History of the Orient, 51/2 (2008): 181-208.
}

By Kerry Muhlestein, Ph.D.

Associate Professor of Ancient Scripture and Ancient Near Eastern

Studies

Brigham Young University

\begin{abstract}
Key Words

Execution

Punishment

Human Sacrifice

Burning

Curses
\end{abstract}

The pages of this journal, and other publications, have seen disagreement in the past regarding the methods of and reasons for sanctioned killing in Ancient Egypt. Some of this disagreement stems from having looked at large expanses of time without regard to change, and to arbitrarily imposed limitations. By looking at a larger corpus of evidence and restricting the examination to a specific period of time, this paper establishes that the Middle Kingdom engaged in a number of methods of sanctioned killing for more reasons than has often been supposed. 


\section{Royal Executions}

\section{Evidence Bearing on the Subject of Sanctioned Killing in the Middle Kingdom}

Kerry Muhlestein

Recent scholarship has expressed some disagreement about capital punishment in ancient Egypt. "What were the reasons for capital punishment?" and "what forms did capital punishment take?" are some of the questions over which we have argued. For example, Lorton writes that capital punishment was carried out only for high treason. ${ }^{1}$ Goedicke infers such, ${ }^{2}$ and Müller-Wollermann believes that treason and royal tomb robbery were the only crimes we can be sure warranted a death sentence (page 182). ${ }^{3}$ In a positive step forward, besides crimes against the king and state, Bazin adds desecration of sacred land to the list of potential capital offenses. ${ }^{4}$ However, a closer examination of the evidence, coupled with reflection on methodology and historiography, yields the conclusion

\footnotetext{
${ }^{1}$ See, for example, David Lorton, "The Treatment of Criminals in Ancient Egypt," Journal of the Economic and Social History of the Orient 20, no. 1 (1977): 11, 15-18.

${ }^{2}$ Hans Goedicke, Königliche Dokumente aus dem alten Reich, Ägyptologische Abhandlungen Bd. 14 (Wiesbaden: Harrassowitz, 1967), 218.

${ }^{3}$ Renate Müller-Wollermann, Vergehen und Strafen: zur Sanktionierung abweichenden Verhaltens im alten Ägypten (Leiden: E.J. Brill, 2004), 196.

${ }^{4}$ Laure Bazin, “Enquête sur les Lieux D'Exécution dans l'Égypte Ancienne," Égypte, Afriqe et Orient 35 (2004), 33.
} 
that these issues are worth revisiting. We can refine and expand our view both as to why execution was enacted and the method by which it was done.

One issue requiring correction is that most of the literature dealing with this topic has focused on the New Kingdom. Some scholars have done so explicitly. ${ }^{5}$ With others, such as Lorton and Müller-Wollermann, it is clear from their conclusions that this time period, compared to others, has disproportionately driven their assessments. This is not surprising because we have more applicable evidence from the New Kingdom than from any other era. Furthermore, that evidence is more detailed and descriptive. However, we are not on safe historiographic ground if we allow New Kingdom documents to dictate conclusions for all of the many eras of Egyptian history; for surely these things changed in some way over long periods of time.

Some of the literature regarding the reasons for and types of capital punishment has sparked response, ${ }^{6}$ leading to academic discussions that have been enlightening and helpful. Heretofore the focus has largely been on particular types of killing, generally examining each kind over enormous time spans. ${ }^{7}$ Such

${ }^{5}$ Such as A. G. McDowell, Jurisdiction in the Workmen's Community of Deir el-Medina (Leiden: Nederlands Instituut Voor Het Nabije Oosten, 1990); and Ellen D. Bedell, "Criminal Law in the Egyptian Ramesside Period" (PhD dissertation, Brandeis University, 1973).

${ }^{6}$ See, for example, Anthony Leahy, "Death by Fire in Ancient Egypt," Journal of the Economic and Social History of the Orient 27, no. 2 (1984): 199, who disagrees with Lorton's translation of a decree that is influenced by Lorton's assumption that capital punishment resulted only from treason.

7 See, for example, Laure Bazin, “Enquête sur les Lieux D’Exécution”, 31-40, who addresses the subject of where execution took place, but flits from time period to time period, 
discussions have helped to establish that a given type of punishment (e.g., burning, ${ }^{8}$ drowning, ${ }^{9}$ or decapitation ${ }^{10}$ ) was a general feature of Egyptian culture (page 183). However, what has been missing is an investigation into the wider topic of sanctioned killing within a narrower time frame. Being specific about type while remaining general about time will not do; nor will a converse investigation be sufficient. It is only by examining both a specific type of punishment over time and the general tendencies of a defined historical context that we will be able to come to a more firm conclusion regarding any punishment in question. ${ }^{11}$

As noted above, most studies have focused on the New Kingdom. A study of sanctioned killing throughout Egypt's history is too great a subject for an article (indeed, I am working on just such a monograph). While recent research demonstrates that in some ways sanctioned killing remained somewhat consistent over time in Egypt, there are also substantial differences between killing in the

covering events from the Old Kingdom to the Roman era as if the place of execution could not have changed over that time period. However, the conclusions are largely driven by evidenced gained from oracles, a practice that is clearly anachronistic for much of Egyptian history.

${ }^{8}$ See Leahy, "Death by Fire."

${ }^{9}$ See Kerry Muhlestein, "Death by Water: The Role of Water in Ancient Egypt's Treatment of Enemies and Juridical Process," in L'Acqua Nell'antico Egitto: Vita, Rigenerazione, Incantesimo, Medicamento, ed. Alessia Amenta, Michela Luiselli, and Maria Novella Sordi (Rome: L'Erma di Bretschneider, 2005), 173-79.

${ }^{10}$ See Jean Capart, “Note sur la décapitation en Égypte,” ZAS 36 (1898): 125-26.

${ }^{11}$ For an analysis and discussion about trends over a long period of time, see Kerry Muhlestein, Violence in the Service of Order: The Religious Framework for Sanctioned Killing in Ancient Egypt, (PhD dissertation, University of California at Los Angeles, 2003). 
New and Middle Kingdoms. ${ }^{12}$ Contrastingly, the sparse evidence of the First Intermediate Period seems to match well with the Middle Kingdom. Some of the debate about types of punishments has focused on the Middle Kingdom, and so it is hoped that an examination of known evidence for sanctioned killing in the Middle Kingdom would be helpful. This study aims to create such an examination and intends to provide a historically sensitive investigation into the nature of sanctioned killing during that era, creating a backdrop that should add meaning to studies - past and future - that discuss specific incidents or types of punishments.

Obviously the Middle Kingdom does not exist in a temporal vacuum; in order to more fully understand this time period, evidence from its cultural precursor (the First Intermediate Period) and successor (early Eighteenth Dynasty) will also be examined when such data enable us to more fully evaluate the existence, nature, or continuation of a given practice. Any study of a specific era must balance between the two ends of a methodological continuum (page 184). One cannot ignore the impact of the past on any time period nor that time period's influence on the future. Nevertheless, one must also avoid a tendency that plagues our discipline, namely, the a-historical approach that picks incidents and evidences from anywhere within Egypt's long history and applies all such data with equal weight to the matter at hand. Here we will examine the Middle Kingdom assemblage, specifically noting when evidence from chronologically

\footnotetext{
${ }^{12}$ See Muhlestein, Violence in the Service of Order.
} 
neighboring eras is used and the reasons for doing so. Tracing the trends revealed in this article to other periods of history must wait for another day.

Other problems that must be addressed are highlighted by the studies noted above. Lorton's, Goedicke's, and Müller-Wollermann's writings have helped us understand some of the issues surrounding execution, but they are also problematic. Lorton's study was an initial investigation into the topic. Such undertakings, while inherently limited, are to be applauded. In essence, Lorton set a standard for others to tilt at, and we should fully expect that continued tilting will reveal defects in the target (there are no targets without defect). However, Lorton allowed his initial conclusion about treason being the only reason for execution to dictate how he translated his sources, rather than letting the sources dictate his conclusion. Goedicke did the same, which led him to invoke a circular argument wherein he insists that a text cannot be translated as meaning someone would be executed for interfering with a funerary cult because this would imply capital punishment. ${ }^{13}$ Elsewhere he takes a somewhat modified stance, arguing that adultery may be worthy of death. ${ }^{14}$ These issues will be dealt with below, but we must be cognizant of the need to let evidence drive our conclusions.

While her work on the general topic of punishment is admirable, MüllerWollermann is greatly hampered in her assessment of the death penalty. She

\footnotetext{
${ }^{13}$ Goedicke, Königliche Dokumente, 218.

${ }^{14}$ Hans Goedicke, "Was Magic Used in the Harem Conspiracy Against Ramesses III?"
} 
largely limits herself by accepting only texts that used the Middle Egyptian term

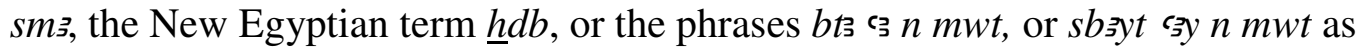
representing capital punishment. ${ }^{15}$ Additionally, the topic (all kinds of punishment) and time span she covers are so great, she cannot delve into great detail for most eras. Moreover, she allows as evidence only texts that indicate that the punishment has been enacted (page 185). ${ }^{16}$ Such texts-for example, those associated with the Great Tomb Robberies (which noted death for robbery of nonroyal tombs, contra her assertion ${ }^{17}$ ) or the Harem Conspiracy-are so rare that their existence is probably due both to a change in administrative decorum as to what could be recorded coupled with the medium on which it was recorded (note that Weni, in his tomb inscription, says very little about the harem matter, which he adjudicated ${ }^{18}$ ) and to the accident of preservation. By disallowing other types of attestation, she has arbitrarily decided that most evidence is inadmissible. In relegating proscriptions with a described death penalty to the realm of "Höllenstrafen," 19 she so limits her evidence that her conclusions will inevitably be skewed. This problem is compounded by her failure to consider the manner in which nonjuridical texts can still inform us of cultural elements that were familiar

Journal of Egyptian Archaeology 49 (1963): 89.

${ }^{15}$ Müller-Wollermann, Vergehen und Strafen, 196.

${ }^{16}$ Ibid., 197.

${ }^{17}$ See J. Capart, A. H. Gardiner, and B. Van de Walle, "New Light on the Ramesside Tomb-Robberies," Journal of Egyptian Archaeology 22 (1936): 171.

${ }^{18}$ Urk. 1:99, lines 5-6. 
to the authors of these texts. This will also be discussed more fully below. In general, this study will attempt to cast a larger net by examining more kinds of evidence and allowing each datum to stipulate its own limitations.

Since one of the purposes behind this study is to establish that execution was enacted for reasons other than treason, I will examine the evidences for sanctioned killing grouped according to the ostensible actions that brought about the punishment. In so doing, the manners in which execution was accomplished will become apparent. It should also be noted that a discussion of the theoretical and social reasons for sanctioned killing are outside of the scope of this study. Such has been done by others, including myself, elsewhere. ${ }^{20}$ However, that topic is too broad for this discussion. In this study, when I speak of reasons for execution, I mean the specific acts that were deemed worthy of death, not the underlying religious or social framework for enacting sanctioned killing at all.

\section{Treason}

Lorton's study was the first to systematically examine the reasons for punishments (page 186). He must be given due credit, for his work is foundational

\footnotetext{
${ }^{19}$ Müller-Wollermann, Vergehen und Strafen, 197.

${ }^{20}$ See Muhlestein, Violence in the Service of Order, 357-88; and Jan Assmann, “Ägypten und die Legitimierung des Tötens: Ideologische Grundlagen politischer Gewalt im Alten Ägypten," in Töten im Krieg, ed. Heinrich von Stietencron and Jörg Rüpke (Freiburg: K. Alber, 1995), 57-83. For a general discussion on capital punishment across cultures, see Keith F. Otterbein, The Ultimate Coercive Sanction: A Cross-Cultural Study of Capital Punishment (New Haven: HRAF Press, 1986).
} 
and necessary reading for any who delve into this topic. As noted above, his initial investigations sometimes give way to further examinations as we refine our knowledge. At first blush, treason is the capital offense for which we have the greatest abundance of evidence and the surest interpretations regarding that evidence. However, when examining the data available for the Middle Kingdom, treason does not take such a primary position. Nevertheless, it certainly must have been an important reason for execution in the Middle Kingdom.

Our most informative text regarding rebellion against the king is the Teaching for Merikare. Whether this instruction was authored in the First Intermediate Period (just before the Middle Kingdom), ${ }^{21}$ Middle Kingdom, ${ }^{22}$ or early Eighteenth Dynasty (just after the Middle Kingdom), it reflects a view that must be associated with the Middle Kingdom in some way. ${ }^{23}$ While it is likely pseudepigraphic, it is still a piece that reflects the topos of its time. ${ }^{24}$ Yet concurrently, its fictionality allows it to address elements that are not usually broached in topos-centered texts. ${ }^{25}$ Additionally, as Lorton writes, "while this is

\footnotetext{
${ }^{21}$ See Miriam Lichtheim, "Didactic Literature," in Ancient Egyptian Literature: History and Forms, ed. Antonio Loprieno (New York: E.J. Brill, 1996), 247.

${ }^{22}$ See Richard Parkinson, The Tale of Sinuhe and Other Ancient Egyptian Poems (Oxford: Oxford University Press, 1997), 212.

${ }^{23}$ Ibid.

${ }^{24}$ Miriam Lichtheim, Ancient Egyptian Literature: a Book of Readings. Volume I: The Old and Middle Kingdoms (Berkeley: University of California Press, 1973), 97.

${ }^{25}$ Parkinson, Tale of Sinuhe, 15-16.
} 
not a juridical text, there is every reason to suppose that it reflects juridical realities." 26

In this text Merikare is admonished to "punish in accordance [with the crime]." ${ }^{27}$ Many crimes discussed in the testament demand lesser punishments than that with which we are concerned. However, there are sections that are revealing for our purposes. One such section states: "Do not strike down ( $m s k r$, it will not be helpful to you ( $n n$ st $3 h n=k$ ). Punish with beatings, with captivity, and thus will the land be established (page 187). Except for the rebel (sbi) whose plans are discovered, for god knows those who plot treason, god smites his obstacles in blood ( $h w i$ intr $s \underline{d b} w=f h r$ snfw). ${ }^{28}$ Note that after the text advises that punishments less severe than death are usually preferable, it then expresses that god will smite the rebel. However, it is clearly the godlike king who must carry this out, lest he lose his throne. This is made more transparent in the admonition, "He who is silent toward the violent ( $g r w r s h m-i b)$ diminishes the offerings. God will attack one who rebels against the temple (tkk ntr sbi hrr $r$

\footnotetext{
${ }^{26}$ Lorton, "Treatment of Criminals," 51.

${ }^{27}$ P. Leningrad 1116A and P. Moscow 4658, as in Joachim Friedrich Quack, Studien zur Lehre für Merikare (Wiesbaden: O. Harrassowitz, 1992). Also used is Aksel Volten, Zwei altägyptische politische Schriften. Die Lehre für König Merikare (Pap. Carlsberg VI) und die Lehre des Königs Amenemhet (København: Einar Munksgaard, 1945). Reconstruction stems partially from my agreement with Lichtheim, Egyptian Literature vol. I, 99.

${ }^{28}$ P. Leningrad 1116A, lines 47-50; Lorton, "Treatment of Criminals," 13, feels that only intentions are spoken of, and thus the king cannot punish, but only god. He musters no evidence that the king cannot punish for intent, applying this Western ideal in the face of examples of the king punishing for intent in later periods, such as in the Harem Conspiracy.
} 
pr). ${ }^{, 29}$ Again the reference is to god attacking the rebel, but implicitly Merikare is warned that this attack must come from him because of the danger in being silent toward violence. While this does not stipulate a death sentence, such is made clear in an earlier and more broken section of the text where, in the midst of speaking of those who incite rebellion, we read, "Repulse him ( $d r s w)$, kill [him] (smz $[s w]),{ }^{30}$ blot out his name." ${ }^{31}$ From these passages one would surmise, even without evidence of its actuation, that acts perceived as treasonous demanded capital punishment.

Two inscriptions corroborate this conclusion. An Intefiqer, probably the vizier of Amenemhet $\mathrm{I},{ }^{32}$ records that he led victorious campaigns in Nubia. As a part of these he "put fire to their homes ( $r d i=i \not h t m p r w=s n)$, as is done to a rebel against the king (mi irt sbi hr nswt)." ${ }^{33}$ Perhaps Intefiqer exaggerated his successes. Still, his comparison makes no sense and would not have been employed without a referent embedded in existing, known situations. It must have been common knowledge that those who were considered rebels were burned.

${ }^{29}$ P. Lenningrad 1116A, line 110.

${ }^{30}$ Volten, Zwei altägyptische politische Schriften, 8-9, restores “ihn"; Parkinson, The Tale of Sinuhe, 217, restores "his children."

${ }^{31} \mathrm{P}$. Leningrad 1116A, lines 23-24.

${ }^{32}$ Claude Obsomer, Sésostirs I ${ }^{\text {er }}$ Etude chronologique et historique du rétne (Brussells: Connaissance de l'Egypte Ancienne, 1995), 245, is convinced that it is.

${ }^{33}$ Zybn ek Zába, Fritz Hintze, and Miroslav Verner, The Rock Inscriptions of Lower Nubia (Czechoslovak concession), vol. 1 (Prague: Charles University, 1974), 99, inscription no. 73. See also Obsomer, Sésostirs ${ }^{e r}$, 662-63. 
In another inscription a punishment other than burning is implied (page 188). The stela of Sehetepibre, from the time of Senusret III, records that "there is no tomb for him who rebels against His Majesty (nn is $n$ sbi $h r h m=f$ ), and his corpse shall be cast into the waters (iw $\underline{h} \Xi t=f k m \Xi n m w) .{ }^{, 34}$ While the language indicates that rebels were killed, someone who had been burned would not have a corpse that could be thrown into the Nile. Presumably, then, the death sentence could be enacted in a variety of ways.

Another text, arguably from the Middle Kingdom, also makes reference to the appropriate violence of the king. In the Words of Neferti we read, "Rebels are destined for his [the king's] rage [(iw sbiw $n w d n d n=f)$, and the malcontent to his awe ( $\underline{h} k$-ibw $n w \check{s} f \check{s} f w t=f)$. The uraeus at his fore pacifies the malcontent for him (shriti $n=f \underline{h}$ sk-ibw)." 35 Again we have an ideological and a fictive text to draw from. Yet the details it presents grew out of a real cultural context, and at the very least it presents the ideals for which the king must strive. While the wording of the text does not seem to refer to an actual incident of violence, it does address when and why the king should be violent. The "when" is each time there are rebels or malcontents present; the "why" is addressed two couplets later: "Ma' at

\footnotetext{
${ }^{34}$ Stela of Sehetepibre as in Karl Piehl, Inscriptions Hiéroglyphiques Recueillies en Europe et en Égypt, vol. 3 (Leipzig: J.C. Hinrichsche Buchhandlung, 1895), pl. VI.

${ }^{35}$ P. Lenningrad 1116B, lines 64-65, as in Wolfgang Helck, Die Prophezeihung des Nfr.tj (Wiesbaden: O. Harrassowitz, 1970), 53-54.
} 
will return to its seat, Isfet is driven out (iw məct $r$ iit $r$ st=s isft $d r t i^{36} r$ rwty)., ${ }^{, 37}$

Hence, it seems that the king must be violent against these rebels and malcontents in order to dispel chaos and reestablish order.

The above texts represent the limit of our knowledge concerning death for treason during the Middle Kingdom. The two literary works represent some of the most mimetic type of texts. Undoubtedly there were cases of treason for which people were executed (as indicated by the Intefiqer inscription), but any recording of such acts were likely topos driven, and decorum probably prevented their being recorded, or at least their being recorded on a durable medium. Surprisingly, we find more evidence for sanctioned killing as a punishment for desecrating sacred land than for treason.

\section{Death for Desecration}

The desecration of sacred land, whether tombs (not necessarily royal, contra Müller-Wollermann ${ }^{38}$ ) or temples, was deemed a capital offense (page 189). ${ }^{39}$ A prime (though somewhat problematic) example of this is related in an inscription at the temple of Tôd commissioned by Senusret I. This text is narrative

\footnotetext{
${ }^{36}$ The stative rendering of this verb is according to C25224. P. Lenningrad $1116 \mathrm{~B}$ reads dr si.

${ }^{37}$ P. Lenningrad 1116B, lines 68-69.

${ }^{38}$ Müller-Wollermann, Vergehen und Strafen, 196.

${ }^{39}$ Even today, the violation of religious norms is one of the leading causes of execution in the world. See Otterbein, The Ultimate Coercive Sanction, 107.
} 
in nature, marking the rudimentary beginnings of the genre of Königsnovelle, and hence must be approached with all the critical cautions necessary for literature of a propagandistic nature. Despite whatever exaggerations are a part of this text, it provides a window into the types of punishments that were considered part of the king's arsenal. Exaggerations were probably in the realm of numbers and not the type of action, though we will return to this point later.

Senusret reports that he had found the temple in a state of disrepair. It had become overgrown with weeds, its seals had been broken, portions of the temple wall had been broken down, and fire had been set to sections of the structure. ${ }^{40}$ In response, Senusret punished those guilty of the desecration. Of them it is written that "the valleys filled with the flayed ( $s r h w)$ and the hills with the impaled (pth w)."41

A lacuna makes deciphering the next punishment difficult. Following the above information, the next word is hrwy, or "enemy." Following this word, the upper traces of the "m" owl are visible, and then the text breaks. Significantly, the determinative for hrwy is a bound, headless man ( $)$. Many reasons may lie behind omitting the head of a bound man within a determinative, but it seems

\footnotetext{
${ }^{40}$ See lines X+28-30, as in Donald B. Redford, "The Tôd Inscriptions of Senwosret I and Early 12th Dynasty Involvement in Nubia and the South," JSSEA 17, no. 1/2 (1987): 42 and fig. 2. See also W. Schenkel, Mitteilungen des deutschen Orientgesellschaft 31 (1975): plate 33.

${ }^{41}$ Reconstructions according to Redford, "Tôd Inscriptions," 42. For explanations as to why this should be translated as "impaled" see Redford, "Tôd Inscriptions," n. 68, Muhlestein, Violence in the Service of Order, 142-143, and Wb, 1:565; or Rainer Hannig, Grosses
} 
quite likely that decapitation was the fate that betook the enemies and which was described in the broken section of text (page 190). ${ }^{42}$ Redford reconstructs the punishment as burning. There is some merit to this, since immediately after the lacuna the text reads "him into the flame $(s w r h t) . " 43$ Whether some were decapitated or not, clearly many perpetrators were punished by burning. In all likelihood, the prisoners were struck with a knife and then burned, as happened in other sacrifices. $^{44}$

Others in this incident were undoubtedly beheaded, since we read of the dndn hrwy. ${ }^{45}$ The word dndn usually means "to decapitate," especially when it is followed with knife determinative ( $\bigcirc)$, as it is here. ${ }^{46}$ Adding to this interpretation is that hrwy is again determined by a bound and headless man.

I aver that Senusret intentionally couched the language of the death he inflicted within cultic terms. His language is that "(the knife $)^{47}$ was applied to the

Handwörterbuch Ägyptisch-Deutsch: (2800-950 v. Chr.): die Sprache der Pharaonen, Kulturgeschichte der antiken Welt; Bd. 64 (Mainz: P. von Zabern, 1995), 298.

${ }^{42} \mathrm{Chr}$. Barbotin and J. J. Clère, "L'Inscription de Sèsostris Ier à Tôd," Bulletin del' Institut Français d'Archéologie Orientale 91 (1991), 10, lines 116-21, translate "J'ai commencé à décapiter le rebelle tandis que lui, la Majesté de l'Horus [. . . ] son [sang] du corps, au coeur féroce dans sa jeunesse, [son] abattoir était (peuplé) d'enfants de rebelles, le bétail de l'offrande quotidienne était (composé) d'Asiatiques (?) . . . qui accomplit le massacre de l'assaillant." In this translation they leave out much of the text that is surrounded by broken lines, but they contain the essence of the event.

${ }^{43} \mathrm{X}+30$ as in Redford, "Tôd Inscriptions," 43 and fig. 2.

${ }^{44}$ It was common practice with animal sacrifices, and Prince Osorkon of the Twentysecond Dynasty did just this with Theban rebels.

\footnotetext{
${ }^{45} \mathrm{X}+32$.

${ }^{46} \mathrm{~Wb}, 4: 983$.

${ }^{47}$ Reconstruction by Redford.
} 
children of the enemy ( $m s w h r w y$; again, the headless hrwy is pictured), Asiatics

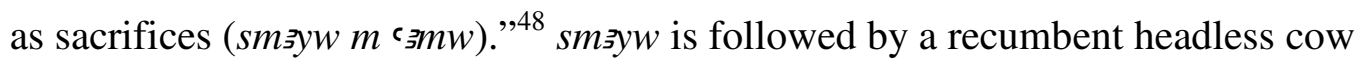
determinative, in which case it always carries a sacrificial meaning. ${ }^{49}$ There can be no doubt that Senusret intended a sacrificial association to be applied to the executions he had just enacted. This point is augmented by the fact that at this period some temple sacrifices were consumed by fire. ${ }^{50}$ Whether modern-day Egyptologists like to associate the Egyptians with human sacrifice or not, it is clear that Senusret did (page 191). ${ }^{51}$

Buchberger has called the dating of this inscription at the temple of Tôd into question. ${ }^{52} \mathrm{He}$ does so because of a number of grammatical and orthographic peculiarities that he believes are difficult to explain in classical Middle Egyptian (though some are not so rare as he thinks). He postulates a New Kingdom dating, or maybe a restoration of an older text in that time period, perhaps under Seti I. ${ }^{53}$ Nevertheless, he does not adequately account for the presence of the name

\section{${ }^{48}$ Line $\mathrm{X}+32$.}

${ }^{49}$ Wb 4:123-24; Hannig, Grosses Handwörterbuch Ägyptisch-Deutsch, 703. See also Redford, "Tôd Inscriptions," n. 81.

${ }^{50}$ Byron E. Shafer, ed., "Temples, Priests, and Rituals: an Overview," Temples of Ancient Egypt (Ithaca: Cornell University Press, 1997), 25. Also see Christopher Eyre, The Cannibal Hymn. A Cultural and Literary Study (Bolton: Liverpool University Press, 2002), 17273.

${ }^{51}$ While it deals with a later time period, see the seminaly study by Error! Main Document Only.Jean Yoyotte, "Héra d' Héliopolis et le Sacrifice Humain," Annuaire - Ecole pratique des hautes aetudes, Section-sciences religieuses 89 (1980-81).

${ }^{52}$ Hannes Buchberger, "Sesostris I. und die Inschrift von et-Tôd? Eine philologische Anfrage," in Karola Zibelius-Chen and Hans-Werner Fischer-Elfert, eds. Von Reichlich Ägyptischem Verstande, Festhschrift für Waltraud Guglielmi zum 65 Geburtstag (Wiesbaden: Philippika, 2006), 15-21. 
"Senusret" in the text. ${ }^{54}$ While this may not be Senusret the First (though Obsomer felt that the inscription fit with the political actions of that monarch ${ }^{55}$ ), the name still suggests a Middle Kingdom context. Buchberger's questions open avenues of investigation into the history of the text after its initial composition, but cast little doubt on its historicity or its original Middle Kingdom context. While the traditional dating is to be preferred, at the very least the inscription indicates something of the Middle Kingdom.

As a type of Königsnovelle we cannot assume that the text has historical qualities. ${ }^{56}$ It is a rough form of the typical story told by many kings, such as Tutankhamun in the Restoration Stela, in which they find the world in a state of chaos and heroically restore order. ${ }^{57}$ In the face of this realization, the easy course would be to dismiss the historicity of the event in favor of its ideology (page 192). However, this course pursues a false dichotomy. Ideological texts are not necessarily bereft of historicity. Dismissing the Tôd inscription because of its

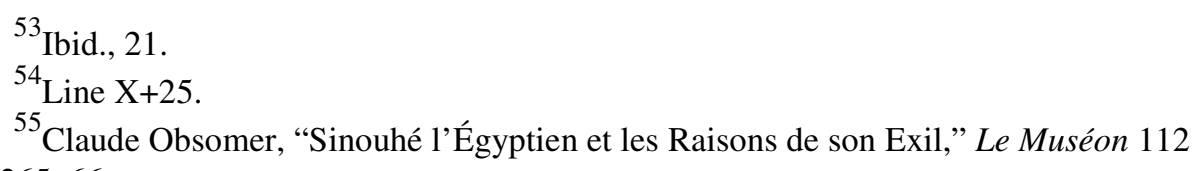

${ }^{56}$ As was pointed out by Wolfgang Helck, "Politische Spannungen zu Beginn des Mittleren Reiches," Ägypten - Dauer und Wandel. Symposium anlaäßlich des 75 jährigen Vestehens des Deutschen Archäologischen Instituts Kairo am 10. Und 11. Okt. 1982, 18 (1985): 49; and Wolfgang Helck, Politische Gegensätze im alten Ägypten (Hildesheim: Gerstenberg Verlag, 1986): 37.

${ }^{57}$ As suggested by Helck, "Politische Spannungen," 49. For just a few other examples, see Urk. 7:27; P. Leningrad 1116B, 69; as in Wolfgang Helck, Die Prophezeihung des Nfr.tj (Wiesbaden: O. Harrassowitz, 1970), 57; Urk. 4:2026; and Stela of Taharqa year 6, lines 3-5 (Kawa version) as in M. F. Laming Macadam, The Temples of Kawa I (London: Oxford University Press, 1949). 
ideological agenda meets with the following problems. (1) Though texts are powerful, they are more powerful when coupled with action. Thus it is likely that if such an event were important enough to create textually, it was probably also important enough to create physically. (2) It is equally as likely that upon encountering a real situation, Senusret I recognized it in ideological terms and responded accordingly. In this case he would have "ideologized" the event, enhancing its numinousity by textualizing it as well. ${ }^{58}$ (3) While undoubtedly most kings took up the role of restoring order, it is inconceivable that they did so only textually. Certainly they all took literal as well as literary actions designed to (a) show their courtiers and people that they were restoring order and (b) ritually/magically actuate the process of destroying chaos and restoring order. Thus it is more problematic to dismiss such events than it is to accept them. Senusret may have invented the situation that brought about his response, but that response was almost certainly real. "History as celebration" is no history. (4) Such an act may have been part of the violence that must have been enacted by Senusret as he strengthened his hold on the throne in the face of whatever rivals were responsible for the assumed assassination of his father. Obsomer holds that the inscription provides details as to his initial purgings. ${ }^{60}(5)$

\footnotetext{
${ }^{58}$ For discussions on these points, see Muhlestein, Violence in the Service of Order, 37083.

${ }^{59}$ Helck, "Politische Spannungen," 49.

${ }^{60}$ Obsomer, "Sinouhé l'Égyptien," 265-66.
} 
Even if the events did not take place, they must still reflect an understanding of the world at the time, just as a fictive novel or movie still reflects types of cars and phones that are real. Beheadings and burnings for desecration of sacred land would not be described unless these were known elements of the world. Whether or not these events happened at this particular place and time, parallels must have occurred elsewhere in Egypt in a time not too distant.

Another potential problem must also be addressed. We should not automatically take the text at its word when it says that Nubians and Asiatics were the guilty parties. Certainly there had been an influx of foreigners into Egypt just before this time (page 193). Also, we know that many prisoners of war were put to work in temples, ${ }^{61}$ so it would not be uncommon to find many foreigners in and around the temple precincts. Moreover, it would not be unusual for foreigners to be depicted as those who embodied Isfet,$^{62}$ and to be chosen as a type of scapegoat for the cultic crimes that had happened at Tôd. It is also possible that the real perpetrators were punished but were described textually as foreigners. We must be careful in extrapolating punishments possibly inflicted on foreigners to the general public. It is quite possible that foreigners or "resident aliens" were more susceptible to harsh punishments than were native Egyptians. However, the

\footnotetext{
${ }^{61}$ See, for example, William C. Hayes, A Papyrus of the Late Middle Kingdom in the Brooklyn Museum (New York: The Brooklyn Museum, 1955).

${ }^{62}$ Antonio Loprieno, Topos und Mimesis. Zum Ausländer in der ägyptischen Literatur, Ägyptologische Abhandlungen, vol. 48 (Wiesbaden: Otto Harrosowitz, 1988), 26.
} 
evidence presented below indicates that death for desecration was not something applied only to nonnatives.

While the propagandistic nature of the Tôd text casts doubt onto many of the details it describes, it also seems inevitable that such practices were part of Senusret I's culture. This incident teaches us something of the reason for and manners of execution. Decapitation, flaying, and burning of rebellious enemies, as well as their being treated as sacrificial slaughter, is manifestly something that was part of the repertoire of royal actions. Decapitation and burning are attested before and after this era, but this is the only known reference to flaying and the first attestation of impalement, though the terminology employed here is unique. ${ }^{63}$ Additionally, desecration is the act that called forth this punishment.

Another text demonstrates that at least some types of desecration were a capital offense: a Middle Kingdom inscription written by Ugaf (1761-59 BC) and later usurped by Neferhotep I (1737-26 BC) ${ }^{64}$ The archaeological context combined with the text make it clear that the stela was designed to designate part of a processional route between the temple and the cemetery as "sacred land" $(t 3$ $\underline{d} s r)$. Any who were found building in or trespassing on this sacred land, excepting a $w a b$ priest acting in his duty, were to be put to death by burning ( $h r t w$

\footnotetext{
${ }^{63}$ See Muhlestein, Violence in the Service of Order, 269-76.

${ }^{64}$ Stela Cairo JE 35256. For translation and commentary see Anthony Leahy, "A
} Protective Measure at Abydos in the Thirteenth Dynasty," Journal of Egyptian Archaeology 75 (1989), 46. 
$b d t w=f$ ). Lorton has argued against burning as a form of punishment and hence translated this as "branded. ${ }^{, 65}$ Breasted provides the same translation. ${ }^{66}$ But Leahy so effectively argues against this translation as to leave no question that it meant death by burning (page 194). ${ }^{67}$ While we will never know if the Abydos decree was violated and the punishment enacted, again, we can be sure that being burned to death was a part of the Middle Kingdom punishment repertoire. Furthermore, we see that in addition to the temple, areas of the necropolis were protected by the threat of death.

A cultural continuation of the practice of inflicting death for desecration of tomb and temple is evident throughout the New Kingdom. ${ }^{68}$ In fact, this punishment was extended to theft of royal or temple property, ${ }^{69}$ even objects as simple as copper tools. ${ }^{70}$

Another evidence, while it is not execution for desecration, is worthy of note because of its cultic connotations. The slaying at Mirgissa, a Middle

${ }^{65}$ Lorton, "Treatment of Criminals," 18.

${ }^{66}$ James Henry Breasted, Ancient Records of Egypt, vol. 1 (Chicago: University of Chicago Press, 1906), 338.

${ }^{67}$ Leahy, "Death by Fire," 199.

${ }^{68}$ See Muhlestein, Violence in the Service of Order, 185-87 and 225-30.

${ }^{69}$ Ibid., 198-204.

${ }^{70}$ See Ibid., 182-85; Ostracon Nash 1, Verso lines 2-3, as in Jaroslav Cerny and Alan H. Gardiner, Hieratic Ostraca (Oxford: Oxford University Press, 1957), pl. XLVI; McDowell, Jurisdiction in the Workmen's Community, 221; Bedell, "Criminal Law," 14, 149; and Morris Bierbrier, The Tomb-Builders of the Pharaohs (London: British Museum Publications Ltd., 1982), 106. 
Kingdom fort built along the banks of the Nile in Kush, ${ }^{71}$ is mentioned here because the sacrificial connotations are similar to those at the temple of Tôd. At Mirgissa, in a Middle Kingdom context, over 175 execration texts were found alongside the remains of a man who was forced to participate in the execration rites. ${ }^{72}$ Nearby were the remnants of many figurines ${ }^{73}$ and a flint knife. ${ }^{74}$ Ritner has convincingly demonstrated that this was the traditional blade for ritual slaughter (page 195). ${ }^{75}$ About twenty centimeters from the knife, a human skull was found buried upside down in a pottery cup with its mandible missing. ${ }^{76}$ The rest of the body had been discarded. ${ }^{77}$ Examination suggested that the body was that of a Nubian. ${ }^{78}$ This was undeniably the human counterpart to the clay figures

${ }^{71}$ See Stephan J. Seidlmayer, Gräberfelder aus dem Übergang vom Altern zum Mittleren Reich. Studien zur archäologie der Ersten Zwischenzeit (Heidelberg: Heidelberger Orientverlag, 1990), 488, who writes that "the most important find relating to execration rituals of the Middle Kingdom comes from outside the Egyptian fortress at Mirgissa in Lower Nubia"; also Andre Vila, “Un Depot de Textes D’Envoutement au Moyen Empire," Journal des Savants 41 (1963); and Yvan Koenig, "Les textes d'envoûtement de Mirgissa," RdE (1990), 101-128.

72 See Kerry Muhlestein, Error! Main Document Only."Execration" in UCLA Encyclopedia of Egyptology, http://www.uee.ucla.edu (May, 2008).

${ }^{73}$ Andre Vila, "Un rituel d' envoûtement au Moyen Empire Égyptien," in L'Homme, kier et aujourd'hui. Recueil d' ètudes en hommage a' Andrè Leroi-Gourhan, ed. Marc Sauter (Paris: Éditions Cujas, 1973), 631, n. 15; and Ritner, Mechanics, 163.

${ }^{74}$ Vila, "Un rituel d' envoûtement," 638.

${ }^{75}$ Ritner, Mechanics, 163-67, especially see n.758.

${ }^{76}$ Vila, 145-47 and fig. 6; Koenig, "Les textes d'envoûtement de Mirgissa," 309 and fig. 4; and Ritner, Mechanics, 163.

${ }^{77}$ Vila, "Un rituel d' envoûtement," 628-31; and Ritner, Mechanics, 163.

${ }^{78}$ Vila, "Un rituel d' envoûtement," 637-38. 
of the ritual. ${ }^{79}$ Ritner calls it "indisputable evidence for the practice of human sacrifice. ${ }^{80}$

This conclusion is strengthened when viewed in light of evidence of the continuation of the practice. Excavations at Avaris have uncovered what is certainly an execration pit as well as what is likely another such pit from an Egyptian strata associated with Ahmose. Locus 1055, the first pit, contained three male skulls, attesting to human inclusion in the execration rites. ${ }^{81}$ Adding to the sacrificial context is the fact that deposited next to the skulls were the fingers from the right hands of three male individuals, likely the same three individuals whose skulls were present. ${ }^{82}$ This demonstrates that severing limbs was part of the rite, as was the custom with sacrificial bulls. The pit is starkly reminiscent of offering the head and foreleg of a sacrificial animal. Moreover, one excavator, Fuscaldo, is convinced that Avaris Locus 1016 was also an execration pit. ${ }^{83}$ Bietak, Dorner and Janosi are less sure. ${ }^{84}$ Within the pit two male skeletons were found, lying face down. Fuscaldo believes that the conditions and circumstances

\footnotetext{
${ }^{79}$ Ibid., 628-31.

${ }^{80}$ Ritner, Mechanics, 162-63.

${ }^{81}$ Perla Fuscaldo, "Tell al-Dab'a: Two Execration Pits and a Foundation Deposit," in Egyptology at the Dawn of the Twenty-first Century. Proceedings of the Eighth International Congress of Egyptologists, Cairo, 2000, vol. 1, ed. Zahi Hawass (New York: The American University in Cairo Press, 2003), 186.

${ }^{82}$ Manfred Bietak, Josef Dorner, and Peter Janosi, “Ausgrabungen in dem Palastbezirk von Avaris Vorbericht tell El-Dab'a/'Ezbet Helmi 1993-2000,” in Ägypten \& Levante 11 (2001): 62-64. I am grateful to Harco Willems for pointing this out to me.

${ }^{83}$ Fuscaldo, “Tell el-Dab'a,” 186.

84 Bietak, et. al., “Ausgrabungen in dem Palastbezirk von Avaris," 67-74.
} 
of the skulls indicate an execration rite similar to that which deposited a skull at Mirgissa (page 196). She also avers that whereas at Mirgissa the next nearest execration pit contained broken figurines, at Avaris the figurines did not serve as a substitute, but the humans they would have represented were used instead, as evidenced by the two full skeletons. ${ }^{85}$ After the Avaris finds, Mirgissa no longer stands as the single attestation of ritual human execration slaughter. It is likely that there were other occurrences besides these that we have either not yet discovered or recognized.

It could be argued that the separation of the heads from the bodies at Mirgissa and Avaris was done posthumously. Such an argument would ignore the power of the ritual itself. Smashing intact texts and figurines is mirrored much better and more powerfully in the slaying of a live human than in the dissection of a dead one. One would have to be looking for reasons not to see the ritual slaughter of a human to take this point of view.

A more important point is that there is an essential difference between capital punishment proper and the ritual slaying of what is most likely a captured enemy. We do not know whether or not those ritually slain at Mirgissa or Avaris were enemies, but it seems the most probable case. The killing of an enemy is certainly not equivalent to killing a native citizen, yet the execution of a captured enemy is somewhat akin to it. The difference between killing on a battlefield and

\footnotetext{
${ }^{85}$ Fuscaldo, “Tell el-Dab'a,” 187-88.
} 
killing a subdued, controlled enemy is greater than the difference between killing a subdued enemy and a subdued rebellious citizen. We must even ask, since the execration rituals were connected with the "rebellion formula," if rebellious citizens could be the ritual victims. This is more likely at Avaris than Mirgissa. Unless those who were forced to take part in these rites were rebellious citizens (and because of the lack of evidence, we cannot know), this is not a case of capital punishment proper. However, it does still tell us something of a societal willingness to engage in sanctioned killing and provides another example of slaying in a ritual context.

\section{Execution for Criminal Offenses}

We have little in the way of solid evidence for capital punishment for criminal acts during the Middle Kingdom, yet the bits and pieces we do have create a mosaic impression that this was a standard practice during the era. For example, adultery may have been viewed as a capital offense (page 197). Some have seen this in the Instructions of Ptahhotep. Goedicke writes that these instructions designate a death penalty for adultery. ${ }^{86}$ The lines he refers to are more ambiguous than he indicates. The Instruction informs the reader that being involved sexually with the women of another house is "a small moment, like a

\footnotetext{
${ }^{86}$ Goedicke, "Was Magic Used?" 89.
} 
dream, and one reaches death by knowing them" (iw phtw mwt hr rh st). ${ }^{87}$ While this phrase could mean that such licentiousness was a capital crime, this is not the only interpretation possible for these lines. Eyre believes that the consequence was indeed death but that "this death was, however, expected as the revenge of the deceived husband, not as the result of criminal proceedings." 88

Eyre's assumption may be buttressed by the fictive tale preserved in Papyrus Westcar, wherein the adulterous wife of a nobleman was burned for her crime (literally, "fire was put" ( $r d i$ ht $)$ on her),${ }^{89}$ and her lover was given to a crocodile, all at the husband's instigation. Some have argued that this represents a real punishment. ${ }^{90}$ Müller-Wollermann dismisses the possibility, stating that this literary text does not conform to nonliterary texts. ${ }^{91}$ While the punishment is fictive, and the concept of death for adultery stands on shaky and speculative ground, Goedicke and Eyre have made a case, and in her quick dismissal MüllerWollermann both ignores their arguments and stands on an argument of silence.

Whether the tale reflects real practice or not, it tells us nothing as to whether death for adultery was administered by husband or state because in the

\footnotetext{
${ }^{87}$ P. Prisse, col. 9, lines 7-11.

${ }^{88}$ C. J. Eyre, “Crime and Adultery in Ancient Egypt,” Journal of Egyptian Archaeology 70 (1984), 97.

${ }^{89}$ P. Berlin 3033, col. 4, line 9. See Georges Posener, Le Papyrus Vandier (Paris: Institute Francais d'Archéologie Orientale, 1985), 32, both the text and n. 3. Posener also compares this to the late Teachings of Ankhsheshonqy.

${ }^{90}$ See Bedell, "Criminal Law," 163, and Wolfgang Boochs, "Religöse Strafen," in Religion und Philosophie im Alten Ägypten, ed. Ursula Verhoeven and Erhart Graefe (Leuven: Uitgeverij Peeters, 1991), 62.
} 
story the revenge of the husband does not culminate in death until the king's approval is received. This tale is highly fanciful, and while it may reflect a general knowledge of adultery as a capital crime, extrapolating such is highly problematic. Even less reliable is Herodotus' tale of Pheros burning women of infidelity $^{92}$ - the story is so full of imaginative elements as to be of no use to us (page 198). Note that the assumptions cited thus far about death being inflicted by the wronged spouse have not included a female as the wronged spouse, an area that needs further research. Furthermore, from the letters of Deir el-Medina in a later time period, we know of accusations of adultery that did not seem to be connected with criminality, ${ }^{93}$ though this is argumentum ex silentio. In the face of such ambiguity, the most we may posit is the possibility that a death sentence was or could be attached to adultery.

Further and tantalizing understanding is offered by an interesting fragment of an administrative document that indicates that the criminal act of a royal slave running away could be considered a capital offense. This papyrus reads, "I found the royal servant Sobekemheb, for he had fled ( $g m n=i h m-n s w$ sbk-m-hb $m t$ $w n n=f w r$ ). See, I gave him to the Court of Hearings ( $m t$ rdin=i sw $r \underline{h n r t} n s \underline{d m}$ ).

\footnotetext{
${ }^{91}$ Müller-Wollermann, Vergehen und Strafen, 197.

92 Herodotus II, 111.

${ }^{93}$ For example, $\mathrm{P} z-n b$ and Mry-Shmt seem to be guilty of adultery, probably more than once, and yet suffer no criminal ramifications. However, they are both also known for their deft bribery and manipulation of the bureaucratic system. See Jac J. Janssen, "Two Personalities," in Gleanings from Deir el-Medina, ed R.J. Demarée and Jac. J. Janssen (Leiden: Nederlands Instituut voor het Nabije Oosten te Leiden, 1982), 114, 119-20.
} 
... He is given to his death in the Hall of Speaking $(\operatorname{dit}(w) m(w) t=f m h z h w h$ $m w) .{ }^{, 94}$ It is worth noting that evidence indicates that fleeing conscripted workers were condemned to a life of forced labor, while runaway slaves—or at least royal runaways, as inferred from this text—could be executed. ${ }^{95}$ The forthrightness of the language in this text provides very strong evidence that fleeing (royal?) slaves who were caught were potentially executed.

A more ambiguous piece of evidence comes from funerary literature. One of the Cannibal Hymn's Coffin Text descendants refers only to the slaughter of cattle $;{ }^{96}$ however, another states that both cattle and human evildoers were to be slaughtered. ${ }^{97}$ While we must be careful in extrapolating anything from funerary literature, of this particular recopying, Eyre correctly writes that while the recopying of the Cannibal Hymn essentially in its original form probably represented a textual transmission, the transmission from the Pyramid Texts to the Coffin Texts in a similar but different form "seems more likely to involve a

${ }^{94}$ P. UC32209, 1.4-6 and 2.4-5, as in The UCL Lahun Papyri: Letters, ed. Mark Collier and Stephen Quirke (Oxford: The Basingstoke Press, 2002). Collier and Quirke translate the last line as "so you seem to be letting him die/languish? In the office of the reporter." Antonio Loprieno, "Slaves," in The Egyptians, ed. Sergio Donadoni (Chicago: University of Chicago Press, 1997), 200, translates, "He will thus be condemned to death in the Hall of the Speaker."

${ }^{95}$ Loprieno, "Slaves," 200.

${ }^{96}$ See CT VI, 179a, and Hartwig Altenmüller, "Bemerkungen zum Kannibalenspruch," in Fragen an die altägyptische Literatur: Studien zum Gedenken an Eberhard Otto, ed. Eberhard Otto et al. (Wiesbaden: Reichert, 1977), 31.

${ }^{97}$ See CT VI, 181h, and Altenmüller, 31. 
continuous development in performative use (page 199)" "98 While the Coffin Text itself may not have ever had an accompanying rite, it probably drew from a common, understood experience: that criminals were executed in some manner, perhaps by burning, given the context of the Cannibal Hymn.

This conclusion is strengthened by looking at inscriptions from the First Intermediate Period such as those on two tombs from Assiut. We will see both a cultural continuity and evidence for slight change between the texts of the First Intermediate Period and the Middle Kingdom, but we must first address the inquiry as to whether or not tomb inscriptions and threats had any bearing on actions in the mortal realm.

In a masterful article that summarizes much of the evidence for violence from the time period, Willems posited that some tomb threats, most notably that of Ankhtifi, could be taken as dictating juridical policies. ${ }^{99}$ Since then, Willems' thesis has seen striking archaeological confirmation in the Avaris execration pit, wherein the fingers of those sacrificed were apparently severed as part of the rite, in a manner very similar to that which Ankhtifi called for in his tomb. ${ }^{100}$ While Willems' ideas met largely with acceptance, they also encountered some strong opposition. Goedicke felt there were serious problems with Willems's

\footnotetext{
${ }^{98}$ Eyre, The Cannibal Hymn, 23-24.

${ }^{99}$ Harco Willems, “Crime, Cult and Capital Punishment (Mo'alla Inscription 8)," Journal of Egyptian Archaeology 76 (1990).

100 Bietak, et. al., "Ausgrabungen in dem Palastbezirk von Avaris,” 60-66.
} 
argument, ${ }^{101}$ though I have pointed out many flaws in Goedicke's

disagreements. ${ }^{102}$ Jan Assmann has argued vociferously, twice, that curses can

refer only to acts that happen outside of this world. ${ }^{103}$ Assmann later modified his

position to reflect that the Ankhtifi curse "is not, then, a curse in the normal sense

but the announcement of laws; malediction and jurisdiction intermingle in a

curious way (page 200)"104

Assmann's strong opinions followed by a change in views demonstrates

the conundrum this issue presents. For example, Morschauser believes that threats

do not dictate events in mortal life at all, ${ }^{105}$ yet he writes, "the threats used in such texts, however, certainly had some roots in the sphere of law; more precisely they are imitative of legal models and concepts."106 Sottas has compared threats from the Old Kingdom with royal decree punitive clauses. ${ }^{107}$ Nordh notes that the

${ }^{101}$ Hans Goedicke, “Ankhtyfy's Threat," in Individu, Société et spiritualité dans l'Égypte Pharaonique et Copte, ed. Christian Cannuyer and Jean-Marie Kruchten (Brussels: Editions \& Imprimerie Illustra, 1993), 111-21.

${ }^{102}$ Muhlestein, Violence in the Service of Order, 126-29.

${ }^{103}$ Jan Assmann, "Inscriptional Violence and the Art of Cursing: A Study of Performative Writing," Stanford Literature Review 9, no. 1 (1992); Jan Assmann, "When Justice Fails: Jurisdiction and Imprecation in Ancient Egypt and the Near East," Journal of Egyptian Archaeology 78 (1992): 162. Eric Doret, "Ankhtifi and the Description of His Tomb at Mo'alla," in For His Ka; Essay Offered in memory of Klaus Baer, David P. Silverman, ed. (Chicago:

Oriental Institute of the University of Chicago, 1994), 79 \& 81, also felt that the inscription could only be cursing left for the divine to enact. However, he provides no evidence nor reasoning for this conclusion, he just states the conclusion as a matter of course.

${ }^{104}$ Jan Assmann, The Mind of Egypt: History and Meaning in the Time of the Pharaohs, trans. Andrew Jenkins (New York: Metropolitan Books, 2002), 99.

${ }^{105}$ Scott Morschauser, Threat-Formulae in Ancient Egypt (Baltimore: Halgo, 1991), 20.

${ }^{106}$ Morschauser, Threat-Formulae, 146. He also discusses this on pp. 20-21.

${ }^{107}$ Henri Sottas, La préservation de la propriété funéraire dans l'ancienne Égypte, avec le recueil des formules d'imprécation (Paris: H. Champion, 1913), 36-40. 
threat formulae used in execration rituals often coincided with a legal enactment of their texts. ${ }^{108}$ Goedicke and Morschauser have outlined threat formula terminology that indicates the pronouncement of capital punishment. ${ }^{109}$ More specifically, Willems has pointed out that the loss of burial and identity prescribed in threats is a well-known juridical punishment. ${ }^{110}$ By the time a person arrived at a tribunal in the next life it would be too late to deny him a burial, indicating that the denial of burial, at least, was intended to be enacted by "the living." Willems also demonstrates that curses of death by fire mirror perfectly texts that are certainly juridical. ${ }^{111} \mathrm{He}$ argues very strongly that tomb curses could be literally acted out. $^{112}$

Despite his objections to a living enactment of threats as outlined above, Morschauser indicates that the punishment for tomb robbing and desecrating-a topic of most curses - was indeed enforced by legal authorities to the extent possible (page 201). ${ }^{113}$ He also outlines several threats, dealing with the disruption of a functioning mortuary cult, which call for specific measures and

\footnotetext{
${ }^{108}$ Katarina Nordh, Aspects of Ancient Egyptian Curses and Blessings: Conceptual Background and Transmission (Stockholm: Gotab, 1996), 95.

${ }^{109}$ Morschauser, Threat-Formulae, 155; and Hans Goedicke, "Juridical Expressions of the Old Kingdom," JNES 15 (1956), 58-59.

${ }^{110}$ Willems, "Crime, Cult and Capital Punishment," 42.

${ }^{111}$ Ibid.

${ }^{112}$ See entire article by Willems.

${ }^{113}$ Morschauser, Threat-Formulae, 146.
} 
adjudication from living officials. ${ }^{114}$ Other curses address property damage to the tomb, asking for similar measures, measures which we know were taken at times. $^{115}$

It seems to me that we are dealing with a false dichotomy in regards to this issue. This is not the place for an in-depth discussion as to why threats may refer to both the mortal and supramortal realm, which I have done elsewhere, ${ }^{116}$ but our insistence that all cursing elements must apply to one or the other is groundless. More to the purposes of this paper, while it is very unlikely that any of the threats discussed below were ever enacted, it is almost indisputable that, as Morschauser argues, they reflect the current juridical practices of the time. After all, as noted above, even Assmann eventually agreed that Ankhtifi's threats were juridical in nature. While the authors of other threats would not have had the same kind of authority to legislate via their inscriptions, they were making a kind of appeal to case law, relying upon the juridical practices they saw around them to inform the curse. As with the Tôd inscription, threat formulae mirror reality in a way similar to novels and movies of today. Thus, when they speak of a royal executioner, we

\footnotetext{
${ }^{114}$ Ibid., 148.

${ }^{115}$ Ibid., 149-51. See also T. Eric Peet, The Great Tomb-Robberies of the Twentieth Egyptian Dynasty (Oxford: Clarendon Press, 1930).

${ }^{116}$ Kerry Muhlestein, "Empty Threats? How Egyptians' Self-Ontology Should Affect the Way We Read Many Texts," in JSSEA 34 (2007): 115-130.
} 
are safe in assuming that such an office existed. With such an assumption in mind, let us examine the relevant texts. As mentioned above, we begin in Assiut.

On the doorjamb of Tomb III the reader is informed that for anyone who failed to protect the tomb or its contents, "his god will not accept his white bread ( $n n \check{s} s p$ ntr $t-h \underline{d}=f$ ), he will not be buried in the West (nn krsti=fi $m$ imnt), and their flesh will burn together with the criminals ( $\left.h w^{w}=s n r t k z h n^{c} \not h b n t i w\right)$, being made one who does not exist (iriw $m$ tmw wnnw)." ${ }^{\prime 17}$ Similarly, at the entrance of Tomb IV we read concerning "any rebel (sbi) and any mal-content $(\underline{h} \xi k-i b)$, who will do wrong ( $\left.p n^{c} y t\right)$ despite having heard these things, his name will not exist ( $n n$ wn $r n=f$ ), he will not be buried in the necropolis ( $n n$ krsti=fi $m$ smit), he will be cooked together with the criminals (iw=f r psit hnc hbntiw) whom god has cursed (page 202)"118 Another Assiut text contains a further element of sanctioned killing. Anyone who failed to recite the desired spell was bound to "fall to the anger of his city-god, and to the slaughter of the king ( $t h s n n s w t$ ). He will not be remembered among the spirits and his name will never again be pronounced on earth ( $n n \operatorname{dmt}(w) r n=f m t z h r n h h)$, he will not be buried in the West, no offerings will be made for him, he will be burned together with the criminals ( $i w=f[r] t k z h$

${ }^{117}$ Elmar Edel, Die Inschriften der Grabfronten der Siut-Gräber in Mittelägypten aus der Herakleopolitenzeit: eine Wiederherstellung nach den Zeichnungen der Description de l'Egypte, Abhandlungen der Rheinisch-Westfälischen Akademie der Wissenschaften Bd. 71 (Opladen: Westdeutscher Verlag, 1984), 25-37 and fig. 5. For other translations, see Willems, "Crime, Cult and Capital Punishment," 37; Assmann, "Inscriptional Violence," 58.

${ }^{118}$ Edel, Die Inschriften der Grabfronten der Siut-Gräber, 120-27, fig. 15. See also 
n' hbntiw)." ${ }^{119}$ Here, besides the burning of criminals reference, we also learn of the existence of "the slaughter of the king," a phrase we will see continued in Middle Kingdom inscriptions. This term may be a euphemism for ritual slaying, with burning, or stabbing and burning, being the specific method employed. Because they mirror the cultural reality of their inscribers, these texts provide strong evidence that criminals were burned, ${ }^{120}$ especially when coupled with the Coffin Text attestation of the practice as noted above.

The First Intermediate Period Coptos Decree R, issued by Demedjibtawy to protect a follower's funerary cult, is more specifically legal in nature. Therein the king dictates that any who interfered with the cult would, among other things, not be "among the living ( $(n h w) . " 121$ While some have argued that the term ' $n h w$ should be translated as something like "free people", elsewhere this phrase is typically rendered literally, and the only argument to the contrary has been that the Egyptians did not execute people. ${ }^{122}$ Without imposing such unsubstantiated a-priori assumptions, the text clearly indicates that a death sentence was intended.

Willems, "Crime, Cult and Capital Punishment," 37; Assmann, "Inscriptional Violence," 59.

${ }^{119}$ Edel, Die Inschriften der Grabfronten der Siut-Gräber, 190-95; Assmann, "Inscriptional Violence," 59.

${ }^{120}$ For a discussion on the function of curses as mirrors of reality, see Muhlestein, Violence in the Service of Order, 107-116.

${ }^{121}$ As in Goedicke, Königliche Dokumente, 213-15.

${ }^{122}$ See Goedicke, Königliche Dokumente, 218. Similarly, Lorton renders the same translation as Goedicke, presumably because of his assumption that capital punishment was not part of the repertoire of the time. See Lorton, "Treatment of Criminals," 11. 
As we continue our examination of tomb threats, we will see a shift in the Middle Kingdom texts, for they contain less about the reasons for and more about the agents of execution (page 203). There are several Middle Kingdom proscriptions carrying threats of death associated with them. One inscription from Lower Nubia states that anyone who destroyed the inscription would "die by the king's execution block $(m w t=f n n m t n s w t) .{ }^{123}$ An alternate translation would be "king's executioner $(n m t(y) n s w t) . " 124$ Both translations are equally possible, and there is no effective difference between the two. I prefer the latter translation because it is more consistent with other contemporary texts. The tenor of the reference makes it nearly certain that the king's executioner/execution block was a real form of punishment with which its inscriber was familiar. Another text states that its damager would die by the hand of the executioner ( $m w t=f n \underline{d r t}$ nmty). ${ }^{125}$ The text leaves us with the inescapable conclusion that execution under the auspices of the king was a part of Middle Kingdom life. Another inscription, as restored by Zába, reads, "as for him who will cut (this), death will be found for him (ir $\check{s} \tau i=f i s w g m n=f m w t) . " 126$ A fourth text is less clear, reading that anyone

${ }^{123}$ Zaba et. al., Rock Inscriptions of Lower Nubia, 81, Inscription no. 57. This translation was also followed by Willems, "Crime, Cult and Capital Punishment," 38.

${ }^{124}$ As was done by Zaba et al., Rock Inscriptions of Lower Nubia, 81-84. See also Laure Bazin, Enquête sur les Lieux D’Exécution," 33.

125 Ibid., 52, Inscription no. 24.

${ }^{126}$ Ibid., 79, Inscription no. 56. 
who destroyed the inscription "will no more sail down stream $\left(n n h h_{d i}=f\right) . " 127$

While not explicitly stated, it can be inferred that such would happen because of the cessation of the perpetrator's life, especially in view of its neighboring inscriptions.

In language which parallels the Ankhtifi inscription, the slightly later Hekaib Stela 9 reads: ${ }^{128}$

As for any governor ( $h$ tti-c $n b)$, any wab-priest, any ka-priest, any scribe $(s \underline{h} z n b)$ or any nobleman ( $s r n b)$, who will take it [the offering] from my statue, his arm will be cut off like a bull ( $s$ hitw hp $\breve{s}=f m i k s$ ) and his neck will be severed like a bird ( $m n t \underline{t} s=f m i$ spd); his position will not exist; the position of his son will not exist; his house in Kush will not exist; his tomb in the necropolis will not exist. His god will not accept his white bread. His flesh is for the fire $(i w=f n h t)$, and his children for the flame $(m s w=f n h t)$.

Many of the punishments described were things we know to have been regularly inflicted, such as the loss of office, house, and tomb (page 204). The rest of the language mirrors sacrificial and burning terminology seen so much elsewhere in this paper.

Similarly, from Knumhotep II's inscription at Beni Hasan we learn of his wishes that anyone who violated the tomb "will not exist $(n$ wnn $=f) . " 129$ Such a

${ }^{127}$ Ibid., 85, Inscription no. 58.

${ }^{128}$ See Labib Habachi, Gerhard Haeny, and Friedrich Junge, The Sanctuary of Heqaib, Elephantine (Mainz am Rhein: P. von Zabern, 1985), 36-37; and Willems, "Crime, Cult and Capital Punishment," 34.

${ }^{129}$ P. E. Newberry, Beni Hasan (London: K. Paul Trench Trübner, 1893), pl. xxv, lines 96-99. 
threat implies that a punishment capable of destroying a person's essence (and thus his afterlife), such as burning, would be employed. ${ }^{130}$ Little could be gained from this inscription alone, but taken together, all these curses paint a convincing picture of capital punishment as a part of the Middle Kingdom milieu, especially at the hand of the king's executioner. The exact manner of execution is unspecified. In the latter texts the reason for capital punishment is not specified, though these seem to be a continuation of the idea that it was criminals (hbntiw) who were being put to death. The Coffin Text reference quoted above adds to the impression that it was hbntiw who were being executed and implies that burning was the method employed.

Criminality is not a very specific term in itself. However, since terms such as $s b i$ and $b \check{s} \underline{t}$ are not employed, the distinction between rebels and criminals seems to be real and meaningful. Unfortunately the types of criminal acts that were deemed worthy of death are not recorded, but we must conclude that some criminal acts were capital offenses.

There is not enough evidence to assess whether or not levels of harshness or of types of punishments were determined by distinction of class. It is tempting to assume that the elite were more immune to capital punishment. However, our most relevant information, the later Harem Conspiracy papyri, do not indicate that such was the case. Despite arguments that suicide—as opposed to execution-

\footnotetext{
${ }^{130}$ See Willems, "Crime, Cult and Capital Punishment," 38.
} 
was afforded those of higher status, ${ }^{131}$ a close examination of the evidence does not bear this out. Among both those who were executed and those who committed suicide, with the exception of a prince, most of the ranks between the groups are essentially equal, with some being identical. ${ }^{132}$ Moreover, the chronological gap between the Middle Kingdom and Ramssess III is large enough that we are no longer on safe grounds for arguing cultural continuity. Thus we must say that the evidence we do have does not argue for differences in execution vis-à-vis social status but that we have too little evidence to accurately assess this idea (page 205).

While the Middle Kingdom does not present us with the type of papyri outlining trials and punishments that we find in the Ramesside Era, we can still arrive at a reasonable view of Middle Kingdom-sanctioned killing. Undoubtedly within Middle Kingdom culture, the Egyptians engaged in sanctioned killing for a variety of reasons and in a variety of ways. These included more causes than robbing royal tombs or treason, unless one defines treason as the breaking of any proscription. While available sources are too vague to enable us to make a comprehensive list of crimes viewed as deserving of death, we can conclude that such a list would at least include (royal?) slaves running away, desecrating sacred ground (at least in certain circumstances), rebellion (the $s b i$ ), and various but

\footnotetext{
${ }^{131}$ Bedell, “Criminal Law,” 169.

${ }^{132}$ Muhlestein, Violence in the Service of Order, 224-25.
} 
unspecified criminal acts (the hbntiw) that perhaps included adultery. While it has been opined that impalement was the normal form of execution, ${ }^{133}$ this is only true of the Ramesside era. ${ }^{134}$ Ritual human slaughter was certainly part of the Middle Kingdom repertoire, as was burning/cooking, beheading, impalement, and flaying. To this list we must add the unspecified yet certain involvement of the royal executioner and his possible execution block. Armed with this broad knowledge about a specific time frame, we are better able to make judgments about individual inscriptions or punishments. It is hoped that many will take up the task of investigating Egypt's juridical processes and punishments in specific topical and historical contexts.

${ }^{133}$ Lorton, "Treatment of Criminals," 51; Müller-Wollermann, Vergehen und Strafen, 197.

${ }^{134}$ See Muhlestein, Violence in the Service of Order, 276. 


\section{Bibliography}

Altenmüller, H. (1977). Bemerkungen zum Kannibalenspruch. Fragen an die altägyptische Literatur : Studien zum Gedenken an Eberhard Otto. E. Otto, J. Assmann, E. Feucht and R. Grieshammer. Wiesbaden, Reichert.

Assmann, J. (1992). "When Justice Fails: Jurisdiction and Imprecation in Ancient Egypt and the Near East." The Journal of Egyptian Archaeology 78: 149-162. . (1992). "Inscriptional Violence and the Art of Cursing: A Study of

Performative Writing." Stanford Literature Review 9: 43-65. . (1995). “Ägypten und die Legitimierung des Tötens: Ideologische Grundlagen Politischer Gewalt im Alten Ägypten.” Töten im Krieg. H. v. Stietencron and J. Rüpke. Freiburg, K. Alber: 57-83. . (2002). The Mind of Egypt: History and Meaning in the Time of the

Pharaohs. New York, Metropolitan Books.

Barbotin, C. and J. J. Clère (1991). "L'Inscription de Sèsostris Ier à Tôd." Bulletin del' Institut Français d'Archéologie Orientale 91: 1-32. (page 206)

Bazin, L. (2004). “Enquête sur les Lieux D’Exécution dans l'Égypte Ancienne.” Égypte, Afriqe et Orient 35: 31-40.

Bietak, Manfred, Josef Dorner, and Peter Janosi. (2001) "Ausgrabungen in dem Palastbezirk von Avaris Vorbericht tell El-Dab'a/'Ezbet Helmi 1993-2000.” Ägypten \& Levante 11: 27-120.

Bedell, E. D. (1973). Criminal Law in the Egyptian Ramesside Period. Mediterranean Studies, Brandeis University.

Bierbrier, M. (1982). The Tomb-Builders of the Pharaohs. London, British Museum Publications Ltd.

Boochs, W. (1991). Religöse Strafen. Religion und Philosophie im Alten Ägypten. U. Verhoeven and E. Graefe. Leuven, Uitgeverij Peeters.

Breasted, James Henry. (1906). Ancient Records of Egypt, vol. 1. Chicago, University of Chicago Press. 
Buchberger, H. (2006). Sesostris I. und die Inschrift von et-Tôd? Eine philologische Anfrage. Von Reichlich Ägyptischem Verstande, Festschrift für Waltraud Guglielmi zum 35 Geburstag. K. Bibelius-Chen and H.-W. FischeElfert. Wiesbaden, Philippka.

Capart, J. (1898). "Note sur la décapitation en Égypte." Zeitschrift für Ägyptische Sprache und Altertumskunde 36: 125-26.

Capart, J., A. H. Gardiner, et al. (1936). "New Light on the Ramesside TombRobberies." The Journal of Egyptian Archaeology 22: 169-93.

Cerný, J. and A. H. Gardiner (1957). Hieratic Ostraca. Oxford, Oxford University Press.

Collier, M. and S. Quirke (2002). The UCL Lahun Papyri: Letters. Oxford, Basingstoke Press.

Doret, E. (1994). “Ankhtifi and the Description of His Tomb at Mo'alla." For His Ka; Essay Offered in memory of Klaus Baer, David P. Silverman, ed. Chicago, Oriental Institute of the University of Chicago.

Edel, E. (1984). Die Inschriften der Grabfronten der Siut-Gräber in Mittelägypten aus der Herakleopolitenzeit : eine Wiederherstellung nach den Zeichnungen der Description de l'Egypte. Opladen, Westdeutscher Verlag.

Eyre, C. J. (1984). "Crime and Adultery in Ancient Egypt." The Journal of Egyptian Archaeology 70: 92-105. . (2002). The Cannibal Hymn. A Cultural and Literary Study. Bolton, Liverpool University Press.

Fuscaldo, P. (2003). "Tell al-Dab'a: Two Execration Pits and a Foundation Deposit." Egyptology at the Dawn of the Twenty-First Century. Proceedings of the Eighth International Congress of Egyptologists. Z. Hawass. New York, The American Univesity in Cairo Press.

Goedicke, H. (1963). "Was Magic Used in the Harem Conspiracy Against Ramesses III?" The Journal of Egyptian Archaeology 49: 71-92. . (1967). Königliche Dokumente aus dem alten Reich. Wiesbaden, Harrassowitz. 
. (1993). Ankhtyfy's Threat. Individu, Société et spiritualité dans l'Égypte Pharaonique et Copte. C. Cannuyer and J.-M. Kruchten. Brussels, Editions \& Imprimerie Illustra.

Habachi, Labib, Gerhard Haeny, Friedrich Junge. (1985). The Sanctuary of Heqaib. Mains am Rhein, P. Von Zabern. (page 207).

Hayes, W. C. (1955). A Papyrus of the late Middle Kingdom in the Brooklyn Museum, (Papyrus Brooklyn 35.1446). Brooklyn, Brooklyn Museum.

Helck, W. (1970). Die Prophezeihung des Nfr. tj. Wiesbaden, O. Harrassowitz. . (1985). "Politische Spannungen zu Beginn des Mittleren Reiches."

Ägypten-Dauer und Wandel Symposium anlasslich des 75 jährigen Vestehens des Deutschen Archäologischen Institute Kairo am 10 Und 11 Okt. 198218.

Verlag. (1986). Politische Gegensätze im alten Ägypten. Hildesheim, Gerstenberg

Janssen, J. (1982). Two Personalities. Gleanings from Deir el-Medina. R. J. Demaree and J. J. Janssen. Leiden, Nederlands Instituut voor het Nabije Oosten te Leiden.

Koenig, Y. (1990). "Les textes d'envoûtement de Mirgissa." Revue d'Égyptologie, 41: $101-25$.

Leahy, A. (1984). "Death by Fire in Ancient Egypt." Journal of the Economic and Social History of the Orient 27: 199-206.

. (1989). "A Protective Measure at Abydos in the Thirteenth Dynasty." The Journal of Egyptian Archaeology 75: 41-60.

Lichtheim, M. (1973). Ancient Egyptian Literature; a Book of Readings. Volume I: The Old and Middle Kingdoms. Berkeley, University of California Press. . (1996). Didactic Literature. Ancient Egyptian Literature : History and Forms. A. Loprieno. Leiden, E.J. Brill.

Loprieno, A. (1988). Topos und Mimesis. Zum Ausländer in der ägyptischen Literatur. Wiesbaden, Otto Harrosowitz. 
. (1997). Slaves. The Egyptians. S. Donadoni. Chicago, University of Chicago Press.

Lorton, D. (1977). "The Treatment of Criminals in Ancient Egypt." Journal of the Economic and Social History of the Orient XX (I): 2-64.

Macadam, M. F. L. (1949). The Temples of Kawa I. London, Oxford University Press.

McDowell, A. G. (1990). Jurisdiction in the Workmen's Community of Deir elMedina. Leiden, Nederlands Instituut Voor Het Nabije Oosten.

Morschauser, S. (1991). Threat-Formulae in Ancient Egypt. Baltimore, Halgo Inc.

Muhlestein, K. (2003). Violence in the Service of Order: The Religious

Framework for Sanctioned Killing in Ancient Egypt. Near Eastern Languages and Cultures. Los Angeles, University of California at Los Angeles.

. (2005). Death by Water: The Role of Water in Ancient Egypt's Treatment of Enemies and Juridical Process. L'Acqua Nell'antico Egitto: Vita, Rigenerazione, Incantesimo, Medicamento. A. Amenta, M. Luiselli and M. N. Sordi. Rome, L'Erma di Bretschneider: 173-79. . (2007) "Empty Threats? How Egyptians' Self-Ontology Should Affect the Way We Read Many Texts," in JSSEA 34 (2007): 115-130. . (2008) "Execration" in UCLA Encyclopedia of Egyptology, http://www.uee.ucla.edu (May, 2008).

Page 208

Müller-Wollermann, R. (2004). Vergehen und Strafen: zur Sanktionierung abweichenden Verhaltens im alten Ägypten. Leiden, E.J. Brill.

Newberry, P. E. (1893). Beni Hasan. London, K. Paul Trench Trübner \& Co.

Nordh, K. (1996). Aspects of Ancient Egyptian Curses and Blessings: Conceptual Background and Transmission. Stockholm, Gotab. 
Obsomer, C. (1995). Sesostirs Ier Egude Chronologique et historique du retne. Brussels, Connaissance de l'Egypte Ancienne. 201-271. (1999). "Sinouhe l'Egyptien et les Raisons de son Exil." Le Museon 112:

Otterbein, K. F. (1986). The Ultimate Coercive Sanction: A Cross-Cultural Study of Capital Punishment. New Haven, HRAF Press.

Parkinson, R. (1997). The Tale of Sinuhe and Other Ancient Egyptian Poems. Oxford, Oxford University Press.

Peet, T. E. (1930). The Great Tomb-Robberies of the Twentieth Egyptian Dynasty. Oxford, Clarendon Press.

Piehl, K. (1895). Inscriptions Hièroglyphiques Recueillies en Europe et en Égypte. Leipzig, J.C. Hinrichsche Buchhandlung.

Posener, G. (1985). Le Papyrus Vandier. Paris, Publications de l' Institut Francais d' Archéologie Orientale.

Quak, Joachim F. (1992). Studien zur Lehre für Merikare. Wiesbaden, O. Harrassowitz.

Redford, D. B. (1987). "The Tôd Inscriptions of Senwosret I and Early 12th Dynasty Involvement in Nubia and the South." The Society for the Study of Egyptian Antiquities Journal XVII (1/2): 36-55.

Ritner, R. (1993). The Mechanics of Ancient Egyptian Magical Practice. Chicago, The University of Chicago.

Schenkel, W. (1975). Mitteilungen des deutschen Orientgesellschaft 31.

Seidlmayer, S. J. (1990). Gräberfelder aus dem Übergang vom Alten zum Mittleren Reich. Studien zur Archäologie der Ersten Zwischenzeit. Heidelberg, Heidelberger Orientverlag.

Shafer, B. E. (1997). Temples, Priests, and Rituals: an Overview. Temples of Ancient Egypt. B. E. Shafer. Ithaca, Cornell University Press. 
Sottas, H. (1913). La préservation de la propriété funéraire dans l'ancienne Égypte, avec le recueil des formules d'imprécation. Paris, H. Champion.

Vila, A. (1963). "Un Depot de Textes D'Envoutement au Moyen Empire." Journal des Savants 41: 135-60.

. (1973). Un rituel d' envoûtement au Moyen Empire Égyptien. L'Homme, kier et aujourd'hui. Recueil d' ètudes en hommage a' Andrè Leroi-Gourhan. M.

Sauter. Paris, Éditions Cujas.

Volten, A. (1945). Zwei altägyptische politische Schriften; die Lehre für König Merikarê (Pap. Carlsberg vi) und die Lehre des Königs Amenemhet. København, Einar Munksgaard.

Willems, H. (1990). “Crime, Cult and Capital Punishment (Mo'alla Inscription 8)." The Journal of Egyptian Archaeology 76: 27-54.

Yoyotte, J. (1981). "Héra d' Héliopolis et le Sacrifice Humain." Annuaire Ecole pratique des hautes aetudes, Section-sciences religieuses 89: 29-102.

Zába, Z. e., F. Hintze, et al. (1974). The Rock Inscriptions of Lower Nubia (Czechoslovak concession). Prague, Charles University. 